\title{
EVALUASI PELATIHAN DASAR (LATSAR) CPNS KEMENTERIAN AGAMA TAHUN 2019 DENGAN MODEL CIPP
}

\author{
Losarini Sumartati ${ }^{1}$, Asih Aryani $^{2}$ \\ ${ }^{1}$ Balai Diklat Keagamaan Bandung, Kementerian Agama, Bandung \\ ${ }^{1}$ Balai Diklat Keagamaan Bandung, Kementerian Agama, Bandung \\ ${ }^{1}$ losarinisumartati@gmail.com; ${ }^{2}$ asiharyani@yahoo.com
}

\begin{abstract}
Abstrak
Penelitian ini bertujuan untuk mengevaluasi kualitas hasil diklat aspek konteks, input, proses dan produk. Metode penelitian ini menggunakan pendekatan kualitatif, menganalisis kegiatan pelaksanaan Pelatihan Dasar CPNS di Balai Diklat Keagamaan Bandung. Penggaliaan data bersumber dari data primer dan data skunder. Data primer berupa kata-kata, sikap atau tindakan yang diperoleh melalui wawancara, observasi secara langsung maupun tidak langsung yang diperoleh dari sumber utama, tim panitia, tim mentor, tim penguji dan peserta Latsar. Data sekunder diperoleh melalui dokumen, kajian terdahulu, buku-buku, agenda rapat, dan yang berhubungan dengan masalah yang sedang diteliti. Hasil penelitian menunjukkan bahwa aspek Conteks adalah sumber hukum yang diterbitkan LAN maupun Pusdiklat, aspek Input terdiri dari empat komponen, yaitu; kurikulum yang sudah ditetapkan oleh LAN sebanyak 511 jp, widyaiswara intern sebanyak 8 orang, ditambah widyaiswara dari luar Instansi, kepanitiaan terdiri dari Penanggung jawab, Ketua, Sekretaris dan dua orang anggota dan peserta, terdiri dari rata-rat 40 orang/angkatan (calon Dosen, calon Guru dan calon Pelaksana). Pada aspek Proses, Kegiatan Pembelajaran Pembentukan Karakter dengan nilai rata-rata 83,74, Kegiatan Pembelajaran Penguatan Kompetensi Teknis, dengan nilai rata-rata 91,56. Aspek Produk terdiri dari: Rancangan Aktualisasi, dengan nilai rata-rata 86,80, Kegiatan Habituasi, dengan nilai ratarata 87,65 dan Laporan Pelaksanaan Aktualisasi, dengan nilai rata-rata 87,81.
\end{abstract}

Kata Kunci: Evaluasi, Pelatihan Dasar, CIPP 


\begin{abstract}
[EVALUASI PELATIHAN DASAR (LATSAR) CPNS KEMENTERIAN AGAMA TAHUN 2019 DENGAN MODEL CIPP]. This study aims to evaluate the quality of the results of the training in context, input, process and product aspects. This research method uses a qualitative approach, analyzing the implementation of the CPNS Basic Training at the Bandung Religious Education and Training Center. Data mining is sourced from primary data and secondary data. Primary data in the form of words, attitudes or actions obtained through interviews, direct or indirect observations obtained from the main source, the committee team, the mentor team, the examiner team and the Latsar participants. Secondary data is obtained through documents, previous studies, books, meeting agendas, and those related to the problem being researched. The results showed that the context aspect was the source of law published by LAN and Pusdiklat, the input aspect consisted of four components, namely; The curriculum has been set by LAN as many as $511 \mathrm{jp}$, internal lecturers as many as 8 people, plus a lecturer, prospective teachers and prospective executors). In the aspect of the Process, Character Building Learning Activities with an average score of 83.74, Learning Activities of Strengthening Technical Competencies, with an average score of 91.56. Product Aspects consist of: Actualization Design, with an average score of 86.80, Habituation Activities, with an average value of 87.65 and Actualization Implementation Report, with an average value of 87.81 .
\end{abstract}

Keywords: Evaluation, Basic Training, CIPP 


\section{PENDAHULUAN}

Sebagai bagian dari warga negara, seorang Aparatur Sipil Negara (ASN) mempunyai peranan yang turut menentukan keberhasilan penyelenggaraan pembangunan. Pardede \& Mustam, (2017) mengatakan bahwa peran utama ASN sebagai pelaksana peraturan perundangundangan, menjalankan fungsi manajemen pelayanan publik, mengelola pemerintahan, manager, ataupun administrator. Seorang ASN harus memiliki kompetensi yang diperlukan baik pengetahuan, sikap maupun perilakunya, sadar akan tanggung jawabnya sebagai seorang pelayan masyarakat, dan harus bisa berperan sebagai perekat persatuan dan kesatuan bangsa. Sosok ASN yang dibutuhkan adalah aparatur yang memenuhi standar kompetensi jabatannya sehingga mampu melaksanakan tugas jabatannya secara efektif dan efisien (Basuki, 2017).

Untuk bisa menciptakan Aparatur Sipil Negara (sebagai Sumber Daya Manusia), tentunya bukan hal yang mudah, diperlukan peningkatan profesionalisme maupun wawasan pengembangan kenegaraan yang menjadi tanggung jawab pemerintah. Sumber daya manusia (SDM) merupakan salah satu faktor terpenting dalam sebuah organisasi, karena sumber daya manusia sangat menentukan keberhasilan pencapaian tujuan organisasi tersebut (Anggraini, 2013).

Pada pasal 70 Undang-undang Nomor 5 Tahun 2014 tentang ASN, dinyatakan bahwa peningkatan profesionalisme ASN, salah satunya dapat dilakukan melalui kegiatan pendidikan dan pelatihan (Diklat). Sudjana (2007) mendefinisikan pelatihan sebagai upaya pembelajaran, yang diselenggarakan oleh organisasi (instansi pemerintah, perusahaan maupun lembaga swadaya masyarakat) guna memenuhi kebutuhan untuk mencapai tujuan organisasi tersebut. Diklat diselenggarakan oleh lembaga yang mempunyai tugas pokok dan fungsi kediklatan dan merupakan bagian dari sistem manajemen kepegawaian (Sdm \& Rahmawati, 2017). Pelatihan adalah proses yang secara sistematik harus mengubah tingkah laku peserta pelatihan untuk melaksanakan tugas pokok dan fungsi yang akan dihadapi kelak di lapangan, dengan cara melakukan perubahan pengetahuan, perilaku, sikap dan keahlian, sesuai dengan bidang tugasnya (Rohaini et al., 2019). Sedangkan Mulyaningsih (2016, 277) mengatakan bahwa pendidikan dan pelatihan merupakan salah satu investasi pada diri seorang aparatur yang nantinya siap dipergunakan apabila diperlukan baik dalam melaksanakan tugas-tugas pemerintahan, pembangunan maupun pelayanan masyarakat.

Kementerian Agama, sebagai salah satu lembaga pemerintah, mempunyai banyak tenaga ASN yang terlibat dalam penyelenggaraan Negara, salah satunya adalah kegiatan pendidikan dan pelatihan (Diklat). Pendidikan dan pelatihan ini menjadi tugas pokok Pusat Pendidikan dan Pelatihan (Pusdiklat) Tenaga Teknis Kementerian Agama. Sesuai Keputusan Menteri Agama No. 1 tahun 2003, bahwa Pusdiklat Tenaga Teknis Keagamaan mempunyai tugas dan fungsi untuk menyelenggarakan Diklat Tenaga Teknis Keagamaan yang bersifat nasional, dengan dibantu Balai Diklat Keagamaan (BDK) sebagai Unit Pelaksana Teknis Kediklatan di daerah. Sasaran Diklat adalah terwujudnya ASN yang memiliki kompetensi sesuai 
dengan persyaratan pada jabatannya masing-masing (Kadarisman, 2015).

$$
\text { Salah satu Diklat yang }
$$
diselenggarakan pada lembaga ini adalah Diklat Prajabatan, yaitu Diklat yang diperuntukkan bagi Calon Pegawai Negeri Sipil (CPNS). Diklat Prajabatan menurut Berliana $(2014,23)$ bertujuan untuk membekali peserta dengan pengetahuan dasar tentang sistem penyelenggaraan pemerintahan negara, bidang tugas dan budaya organisasi agar mampu melaksanakan tugas serta peranannya sebagai pelayan masyarakat, terutama dalam pembentukan wawasan kebangsaan.

Sesuai dengan Peraturan LAN RI Nomor 12 Tahun 2018, istilah Prajabatan diganti menjadi Pelatihan Dasar Calon Pegawai Negeri Sipil (Latsar CPNS), yaitu pelatihan dalam masa prajabatan yang dilakukan secara terintegrasi untuk memperkuat profesionalisme, membangun semangat nasionalisme dan kebangsaan, karakter yang unggul serta kompetensi masing-masing sesuai dengan tupoksinya atau diistilahkan dengan kompetensi bidang.

Kegiatan Latsar CPNS dengan pola yang baru ini, terdiri dari tiga kegiatan, yaitu 18 hari pertama (177 jp) peserta berada di instansi penyelenggara diklat, 30 hari berikutnya (320 jp) peserta diklat berada di tempat tugasnya dan melaksanakan kegiatan habituasi, dan tiga hari terakhir (14 jp), peserta diklat kembali ke instansi penyelenggara untuk melaksanakan seminar hasil aktualisasi.

Formasi CPNS Kementerian Agama Tahun 2018 sekitar tujuh belas ribu orang, yang terdiri berbagai bidang tugas; guru, dosen, penyuluh, penghulu, tenaga adminstrasi dan sebagainya. Untuk melatih CPNS sebanyak ini diperlukan penanganan yang serius dan terintegrasi, mulai dari kegiatan perencanaan,

pengorganisasian, pelaksanaan sampai ke tahap evaluasinya. Kegiatan Latsar CPNS ini yang menjadi rujukan langsung adalah kebijakan yang dikeluarkan oleh Lembaga Administrasi Negara, Kementerian Agama tinggal melaksanakan sesuai dengan ramburambu yang telah ditetapkan.

Pola Latsar CPNS ini baru satu tahun berjalan dilaksanakan di berbagai instansi, termasuk Kementerian Agama. Sebagai program yang baru dilaksanakan, tentu saja masih perlu banyak sosialisasi, pembenahan di berbagai bidang, mulai dari tenaga pengajar (widyaiswara), kepanitiaan, sarana dan prasarana serta dukungan dari atasan langsung peserta Latsar sebagai mentor. Berdasarkan pengamatan awal, pelaksaanaan Latsar CPNS 2019 di BDK Bandung, masih terdapat kekurangan delapan Widyaiswara tenaga administrasi untuk menangani 21 angkatan Latsar CPNS (@40 orang/angkatan), dan dilaksanakan secara kontinyu dengan waktu yang relatif singkat, mulai dari bulan Agustus hingga November 2019. Untuk menangani masalah tersebut, solusi awal adalah mengambil narasumber dari luar serta memberdayakan narasumber yang sudah purnatugas. Selain itu, masih terdapat perbedaan persepsi beberapa coaching dalam pelaksanaan rancangan sampai pelaksanaan aktualisasi. Kondisi yang demikian ini menjadikan kegiatan evaluasi sebagai hal yang tidak boleh diabaikan demi keberlangsungan program ini di masa yang akan datang, sekalipun kegiatan ini sering merupakan bagian yang mendapat respon rendah, karena sebagian berpendapat setelah selesai pelaksanaan, selesai pula kegiatan 
tersebut. (Aryani, 2019).

Tujuan umum sebuah evaluasi program pelatihan adalah untuk mendapatkan data sebagai bahan dasar masukan bagi pengambilan keputusan: a) perencanaan program, pada aspek ini, disusun lokasi program, tujuan, peserta pelatihan, widyaiswara, metode, teknik, media, dana, sarana dan prasarana, dan daya dukung lainnya; b) penghentian, kelanjutan ataupun perluasan program pelatihan, tujuan ini biasanya dilaksanakan pada saat program berjalan (formatif) maupun setelah program dilaksanakan (sumatif); c) modifikasi program pelatihan; d) faktorfaktor yang mendukung ataupun menjadi penghambat program, yang salah satunya dapat diidentifikasi dengan menggunakan analisis SWOT (Strenghts, Weaknesses, Opportunities dan Threats); e) motivasi maupun pembinaan pengelolaan serta pengembangan pelaksanaan program pelatihan; dan f) pengembangan pengambilan landasan filosofis maupun yuridis sebuah evaluasi program.

Evaluasi bukan hanya sekedar kegiatan pengumpulan data lewat pengukuran, tetapi sebuah proses yang berlangsung mulai dari identifikasi outcome, yang berakhir pada sebuah pengambilan keputusan (Ismail, 2014), dan untuk menunjukkan apakah tujuan telah tercapai (Nuraini, 2019). Evaluasi program pelatihan didefinisikan sebagai kegiatan mengumpulkan, mengolah, menganalisa, atau menafsirkan program pelatihan yang dapat dipergunakan sebagai dasar pengambilan keputusan (Rohaini et al., 2019). Kegiatan evaluasi merupakan rangkaian kegiatan yang seharusnya berjalan secara sistematis dan berkelanjutan, karena kegiatan ini merupakan rangkaian untuk mengumpulkan, mendeskripsikan, menginterpretasikan dan menyajikan informasi sebagai dasar yang diambil untuk kebijakan dalam melaksanakan program selanjutnya. Berhasil tidaknya program kegiatan pendidikan dan pelatihan akan banyak bergantung pada kegiatan evaluasi yang dilakukan (Silvia, 2015). Evaluasi penting bagi keberlangsungan sebuah program, karena akan menjadi dasar dalam pengambilan sebuah keputusan, apakah akan dihentikan, diperbaiki, ditingkatkan atau dilanjutkan (Sukardi, 2014).

Pada umumnya, kegiatan evaluasi pelaksanaan sebuah program, ada empat kebijakan yang diambil, yaitu: a) menghentikan program, bila ternyata program yang dijalankan tidak ada atau bahkan kurang manfaatnya, atau bisa juga tidak terlaksana sebagaimana tujuan yang diharapkan; b) merevisi program bila pelaksanaannya masih ada beberapa bagian yang kurang tepat; $c$ ) melanjutkan program bila ternyata pelaksanaan kegiatan sudah sesuai dengan harapan dan memberikan hasil yang menguntungkan; dan d) menyebarluaskan program bila ternyata pelaksanaan program berjalan sesuai dengan yang diharapkan dan bisa dilaksanakan pada kegiatan serupa dengan tempat dan waktu yang berbeda.

Konsep evaluasi yang digunakan dalam penelitian ini adalah konsep evaluasi model CIPP (Context, Input, Process and Product). (Hanun, M.Pd, 2018) menyatakan, CIPP ini pertama kali diperkenalkan oleh Stufflebeam tahun 1965 dengan tujuan utamanya memperbaiki. Evaluasi model ini dapat diterapkan dalam berbagai bidang, termasuk diantaranya evaluasi dalam kegiatan pendidikan dan pelatihan. Model CIPP ini merupakan singkatan dari keempat huruf yang menjadi 
dimensi utamanya, yaitu: a) Context adalah latar belakang yang mempengaruhi strategi-strategi apa yang akan dikembangkan dalam kegiatan yang dilaksanakan. Menggambarkan serta merinci lingkungan, kebutuhan yang harus dipenuhi, populasi dan sampel yang akan dilayani, dan tujuan yang ingin dicapai. Dalam penelitian ini yang dijadikan context adalah landasan kebijakan yang telah dikeluarkan oleh Lembaga Administrasi Negara (LAN) dan Pusdiklat Kementerian Agama; b) Input, bertujuan menyediakan semua hal termasuk informasi untuk menentukan bagaimana menggunakan sumber daya yang sudah disediakan dalam mencapai tujuan program, dan strategi yang dikembangkan dalam kegiatan yang dilaksanakan. Input dalam penelitian ini terdiri dari Kurikulum Diklat, widyaiswara yang mengampu bidang ini, Kepanitiaan yang akan mendampingi selama kegiatan dilaksanakan serta peserta yang mengikuti kegiatan; c) Process, diarahkan pada seberapa jauh kegiatan yang harus dilaksanakan dalam sebuah kegiatan, apakah sudah terlaksana sesuai dengan perencanaan maupun pedoman yang telah ditetapkan yaitu pelaksanaan kegiatan riil di lapangan. Kegiatan pembelajaran yang terbagi menjadi pelaksanaan kegiatan pembentukan karakter serta penguatan kompetensi bidang teknis yang menjadi fokus dari aspek process dalam penelitian ini; d) Product, yaitu digunakan untuk mengukur keberhasilan pencapaian tujuan atau keberhasilan dari keputusan-keputusan yang diambil untuk perbaikan dan aktualisasi hasil pengembangan pengetahuan, karakter maupun sikap yang diperoleh peserta, baik hasil selama kegiatan berlanggung maupun hasil setelah mengikuti kegiatan.

Secara sederhana, kerangka berfikir penelitian ini digambarkan sebagai berikut:

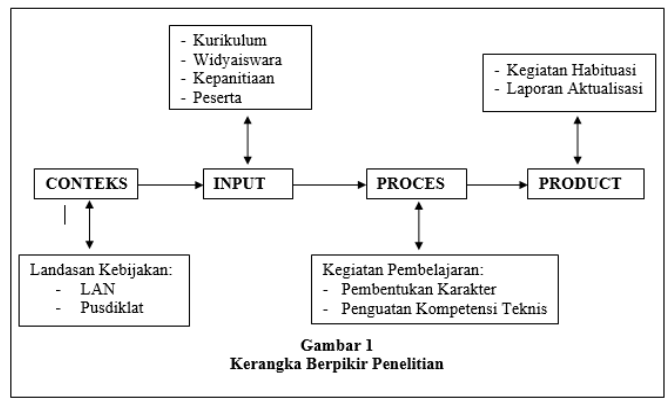

Beberapa kegiatan pendidikan dan pelatihan, sekalipun rutin dilaksanakan, masih belum mendapat hasil yang diharapkan (Hanun, M.Pd, 2018; Mulyaningsih, 2016; dan Tulung, 2014), dengan demikian, evaluasi menjadi sebuah kegiatan yang penting untuk dilaksanakan.

Lebih detailnya, temuan (Hanun, M.Pd, 2018) di Pusdiklat Teknis Keagamaan masih ada beberapa hal yang perlu diperhatikan, yaitu: a) rekruitmen peserta Diklat belum memaksimalkan penggunaan Sistem Informasi Kediklatan; b) Widyaiswara yang melaksanakan Dikjartih (mendidik, mengajar dan melatih) masih missmatch, sehingga hasilnya belum optimal; $c$ ) kedisiplinan panitia rendah, yang mengakibatkan kurang maksimal dalam pelaksanaan tupoksinya; d) ada beberapa ukuran kelas maupun tempat istirahat yang belum memenuhi standar, sehingga kurang nyaman; e) kegiatan ekstrakurikuler minim karena pengajar masih terkonsentrasi pada pemberian materi; f) penyajian makanan masih monoton; g) ketersediaan anggaran belum mencukupi kebutuhan, h) kualitas ketersediaan sarana Diklat, internet dan kelengkapan bahan ajar masih kurang. Tulung (2014), yang melakukan 
penelitian tentang evaluasi Diklat PIM IV di BDK Manado, didapatkan bahwa: a) pada komponen konteks Balai Diklat Keagamaan Manado sudah layak untuk mengadakan Diklat PIM IV, sesuai dengan tupoksinya sebagai lembaga Diklat. BDK Manado juga memiliki dukungan tiga Kanwil Kementerian Agama, struktur organisasi jelas, sumber daya manusia, fasilitas sarana dan prasarana serta dukungan kemitraan dari berbagai instansi dan Perguruan Tinggi; b) pada komponen input disimpulkan bahwa peserta yang mengikuti Diklat PIM IV adalah mereka yang sedang memangku jabatan eselon IV pada Kantor Kementerian Agama dan Perguruan Tinggi Keagamaan di wilayah kerja BDK Manado, serta memenuhi persyaratan administrasi sebagaimana yang tercantum dalam pedoman penyelenggaraan Diklat PIM IV. Untuk komponen Widyaiswara Administrasi yang mengajar pada Diklat PIM IV masih sangat terbatas, sehingga masih memfungsikan beberapa widyaiswara yang sudah purna bakti; c) pada komponen proses ditemukan widsyaiswara dalam hal penggunaan metode mengajar masih kurang memuaskan peserta Diklat karena kurang menerapkan pendekatan andragogik; dan d) pada aspek telah memenuhi kriteria sebagaimana yang tertera pada panduan Diklat PIM IV. Temuan penelitian (Juanda, 2011) didapat bahwa beban mengajar untuk masing-masing Widyaiswara masih terlalu banyak yaitu tiga sampai empat mata Diklat, dengan demikian menjadi pengaruh terhadap kesiapan dan kualitas pembelajaran. Hal ini diperkuat dengan hasil penelitian (Israwati, 2019), menyatakan bahwa Widyaswara yang mengajar pada Diklat Prajabatan tidak semuanya berkompeten sesuai dengan bidang spesialisasinya, dengan materi yang cukup sulit untuk dimengerti oleh peserta pelatihan, sehingga berpengaruh terhadap keberhasilan Diklat. Demikian pula dengan hasil penelitian (Zakiyuddin, 2016) yang menyimpulkan bahwa secara umum pelaksanaan Program Diklat Administrasi Kepegawaian (DAK) sudah cukup berhasil, namun terdapat beberapa aspek/komponen yang perlu diperbaiki dan ditingkatkan demi tercapainya tujuan program. Penelitian (Mulyaningsih, 2016) menemukan bahwa pada aspek peserta, masih ada ketidaksesuaian antara jabatan (tugas pekerjaan sehari-hari) peserta pelatihan dengan materi diklat yang diikutinya. Minimnya fasilitas dan waktu observasi lapangan yang singkat, menjadikan pelaksanaan diklat tidak efektif (Handayani et al., 2014). Pada hasil penelitian (Raharjo, n.d.), ditemukan bahwa nilai nasionalisme pada Diklat Prajabatan dengan pola baru, berpengaruh negatif terhadap kinerja pegawai. Demikian pula evaluasi pelaksanaan kegiatan yang selama ini sudah dilakukan di BDK Bandung masih berupa rutinitas yang sifatnya kurang bermakna, karena tindak lanjut dari evaluasi belum dapat diimplementasikan secara komprehensif.

Berdasarkan uraian di atas, identifikasi masalahnya adalah masih terdapat berbagai kendala yang ditemukan dalam pelaksanaan Latsar CPNS di BDK Bandung. Secara detail identifikasi masalah di atas dirumuskan sebagai berikut: a) bagaimana Context Pelatihan Dasar CPNS Tahun 2019 di Balai Diklat Keagamaan Bandung?; b) bagaimana Input Pelatihan Dasar CPNS Tahun 2019 di Balai Diklat Keagamaan Bandung?; c) bagaimana Proses Pelatihan Dasar CPNS Tahun 2019 di 
Balai Diklat Keagamaan Bandung?; dan d) bagaimana Produk Pelatihan Dasar CPNS Tahun 2019 di Balai Diklat Keagamaan Bandung?

Adapun manfaat yang diharapkan dalam penelitian ini adalah: a) bagi akademisi, menjadi dasar pemikiran bagi pelaksanaan kegiatan Latsar CPNS di masa mendatang, dan b) bagi praktisi, akan menjadi ruang bertindak secara cepat dan akurat pada pelaksanaan kegiatan Latsar CPNS di masa yang akan datang.

\section{METODE PENELITIAN}

Penelitian evaluatif ini bertujuan untuk mendeskripsikan dan menganalisis kegiatan pelaksanaan Pelatihan Dasar (Latsar) CPNS di Balai Diklat Keagamaan Bandung. Pendekatan yang digunakan kualitatif yang berakar pada latar alamiah sebagai keutuhan dan mengandalkan manusia sebagai alat penelitian, mengarahkan sasaran penelitian pada usaha menemukan teori dan dasar, mementingkan proses dari pada hasil (Moleong, 2011:27).

Penelitian kualitatif adalah rangkaian kegiatan atau proses penyaringan data ataupun informasi yang bersifat sewajarnya, seadanya mengenai sesuatu masalah atau kejadian dalam kondisi, aspek atau bidang tertentu dalam kehidupan obyeknya (Nawawi, 2007; 27).

Karakteristik penelitian kualitatif jika dilihat dari sifatnya, bersifat baru, dari sisi tujuannya adalah untuk mendapatkan makna yang mendalam, menyeluruh, komprehensif dan dari sisi instrumennya adalah peneliti sebagai instrumennya sehingga peneliti harus memiliki wawasan mendalam tentang masalah yang diteliti, dilihat dari segi teknik pengumpulan datanya, penelitian kualitatif menggunakan teknik $\begin{array}{llr}\text { pengumpulan } & \text { data } & \text { secara } \\ \text { gabungan/simultan } & \text { yang dilakukan }\end{array}$ melalui wawancara mendalam dengan para informan utama (key-informance), dilihat dari segi analisisnya, penelitian kualitatif menggunakan analisis yang bersifat induktif, yaitu analisis yang bertolak dari fakta-fakta atau data yang ditemukan di lapangan yang kemudian dikonstruksi menjadi sebuah teori, dilihat dari segi fokusnya, penelitian kualitatif tidak terfokus pada generalisasi, melainkan lebih menekankan pada makna yang mendalam yang terdapat pada faktafakta atau data tersebut (Nata, 2009).

Lokasi penelitian adalah Balai Diklat Keagamaan Bandung yang melaksanakan kegiatan Pelatihan Dasar CPNS tahun 2019 (Latsar CPNS 2019), sebanyak 21 angkatan. Sedangkan subyek penelitian adalah seluruh pihak yang terkait dalam pelaksanaan Latsar CPNS 2019, yaitu tim Widyaiswara, tim panitia pelaksana, tim mentor, tim penguji dan peserta.

Pengumpulan data dilakukan melalui wawancara, observasi dan studi dokumentasi. Wawancara dilakukan kepada Widyaiswara, tim panitia pelaksana, tim mentor, tim penguji dan peserta. Observasi atau pengamatan dilakukan baik langsung maupun tidak langsung selama kegiatan Latsar CPNS. dan studi dokumentasi melalui telaah dokumen, kajian-kajian terdahulu, bukubuku, agenda rapat, dan lain-lain yang berhubungan dengan topik penelitian.

\section{TEMUAN DAN PEMBAHASAN}

a. Context

Pada aspek context ini, yang dimaksud adalah latar belakang yang 
mempengaruhi strategi-strategi apa yang akan dikembangkan dalam kegiatan yang dilaksanakan. Pada penyelenggaraan Latsar ini, Balai Diklat Keagamaan Bandung tidak terlepas dari panduan sumber hukum yang menjadi pijakan seluruh pelaksanaan kegiatannya, yaitu: sumber hukum yang diterbitkan LAN maupun Pusdiklat. Dasar hukum tersebut adalah; 1) Peraturan Pemerintah Nomor 11 Tahun 2017 tentang Manajemen Aparatur Sipil Negara, 2) Undang-undang Nomor 5 tahun 2014 tentang Aparatur Sipil Negara, 3) Perkalan Nomor 25 Tahun 2017 tentang Pedoman Penyelenggaraan Pelatihan Dasar Calon Pegawai Negeri Sipil Golongan III, 4) Perkalan Nomor 12 Tahun 2018 tentang Pedoman Penyelenggaraan Pelatihan Dasar Calon Pegawai Negeri Sipil, 5) Peraturan Menteri Agama Nomor 59 Tahun 2015 tentang Organisasi dan Tata Kerja Balai Pendidikan dan Pelatihan Keagamaan, 6) Peraturan Menteri Agama Nomor 75 Tahun 2015 tentang Penyelenggaraan Pendidikan dan Pelatihan pada Pegawai Kementerian Agama, 7) Daftar Isian Pelaksaanaan Anggaran (DIPA) Petikan Balai Diklat Keagamaan Bandung Nomor SP DIPA025.11.2.426191/2019 tanggal 05 Desember 2018, dan 8) Keputusan Kepala Balai Diklat Keagamaan Bandung Nomor: 203/Bdl.05/04/2018 tanggal 16 April 2018 tentang Panitia Penyelenggara Pelatihan Dasar CPNS Golongan III Tahun 2019.

Secara khusus, yang menjadi panduan terbaru pelaksanaan Latsar CPNS ini adalah Peraturan Kepala LAN Nomor 12 Tahun 2018 tentang Pedoman Penyelenggaraan Pelatihan Dasar Calon Pegawai Negeri Sipil (poin 4 di atas). Perkalan ini terdiri dari: 1) Bab I, Ketentuan Umum, yang terdiri dari 5
Pasal (Pasal 1 - Pasal 5), 2) Bab II, Penyelenggaraan Pelatihan Dasar CPNS, yang terdiri dari 5 Pasal (Pasal 6 - Pasal 10), 3) Bab III, Kurikulum Pelatihan Dasar CPNS yang terdiri dari 4 Pasal (Pasal 11 Pasal 14), 4) Bab IV, Kepesertaan Pelatihan Dasar CPNS, yang terdiri dari 2 Pasal (Pasal 15 - Pasal 16), 5) Bab V, Evaluasi Pelatihan Dasar CPNS, yang terdiri dari 5 Pasal (Pasal 17 - Pasal 21), 6) Bab VI, Pengawasan Pengendalian, yang terdiri dari 4 Pasal (Pasal 22 - Pasal 25), 7) Ban VII, Pembiayaan Pelatihan Dasar CPNS, yang terdiri dari 2 Pasal (Pasal 26 dan Pasal 27), 8) Bab VIII, Ketentuan Lain-lain, yang terdiri dari 3 Pasal (mulai Pasal 28 - Pasal 30) dan terakhir 9) Bab IX, Penutup yang terdiri dari 2 Pasal (dari Pasal 31 - Pasal 32).

Perubahan peraturan ini didasarkan pada kepentingan penyempurnaan serta pengayaan pada konsep Diklat Prajabatan yang dikembangkan dengan desain Diklat terintegrasi sesuai dengan perkembangan dan dinamika sebuah jabatan serta penguatan kompetensi sesuai bidang jabatan yang melekat pada tiap-tiap ASN.

Harapan tertinggi dari perubahan peraturan ini adalah terbentuknya karakter PNS serta kemampuan dalam bersikap dan bertindak secara profesional dalan pengelolaan masalah keragaman dan sosiokultural yang berkonsep whole of goverment atau one goverment dengan landasan utama kedudukan serta peran PNS dalam Negara Kesatuan Republik Indonesia (NKRI) sebagai wujud nyata bela negara dalam setiap pelaksanaan tugasnya sehari-hari.

b. Input

1. Kurikulum

Kurikulum yang digunakan pada Latsar CPNS 2019, merupakan 
kurikulum terbaru yang sudah disahkan oleh instansi pembina yaitu Lembaga Adminstrasi Negara (LAN), yang dituangkan dalam Peraturan Lembaga Administrasi Negara Nomor 12 tahun 2018, dengan definisi yang dijelaskan pada Pasal 1 point 8 yang berbunyi:

"Pelatihan Dasar CPNS adalah pengembangan dan pelatihan dalam masa prajabatan yang dilakukan secara terintegrasi untuk membangun integritas moral, kejujuran, semangat dan motivasi nasionalisme dan kebangsaan, karakter kepribadian yang unggul dan bertanggung jawab dan memperkuat profesionalisme serta kompetensi bidang" .

Kurikulum yang terbaru ini, terdapat tujuh komponen, yaitu; (a) Jumlah jam pelatihan 511 JP, @10 JP/hari, (b) Metode pembelajaran; Ceramah 25\%, Diskusi 25\% dan Praktek 50\%, (c) Kegiatan Pembelajaran, terdiri dai 14 mata diklat, yaitu; Dinamika Kelompok, Muatan Teknis Substansi Lembaga (MTSL), Konsepsi Akualisasi, Wawasan Kebangsaan, Analisis Isu Kontemporer, Kesiapsiagaan Bela Negara, Akuntabilitas PNS, Nasionalisme, Etika Publik, Komitmen Mutu, Anti Korupsi, Manajemen ASN, Whole of Government (WoG) dan Pelayanan Publik, (d) Metode Diklat; Ceramah, Diskusi dan Praktek, (e) Tenaga Pengajar, 8 (delapan) orang Widyaiswara Administrasi, (f) Alat bantu latihan, terdiri dari Laptop, printer, plipchart, whiteboard, soundsystem, dan LCD. (g) Peserta, terdiri dari 40 orang/angkatan, kecuali angkatan XXI, terdiri dari 20 orang peserta. Peserta terdiri dari calon Dosen, calon Guru dan calon Pelaksana, yang tersebar dari Kemenag Kota dan Kabupaten di Jawa Barat, UIN SGD Bandung dan IAIN Syekh Jati Cirebon.

\section{Widyaiswara}

Widyaiswara yang terlibat dalam proses pembelajaran Latsar ini terdiri dari delapan Widyaiswara Administrasi BDK Bandung, ditambah dengan Widyaiswara dari Pusdiklat Administrasi, Lembaga Administrasi Negara, Pejabat Struktural, TNI (khusus untuk mata diklat Kesiapsiagaan Bela Negara), dan beberapa Widyaiswara yang sudah purna tugas.

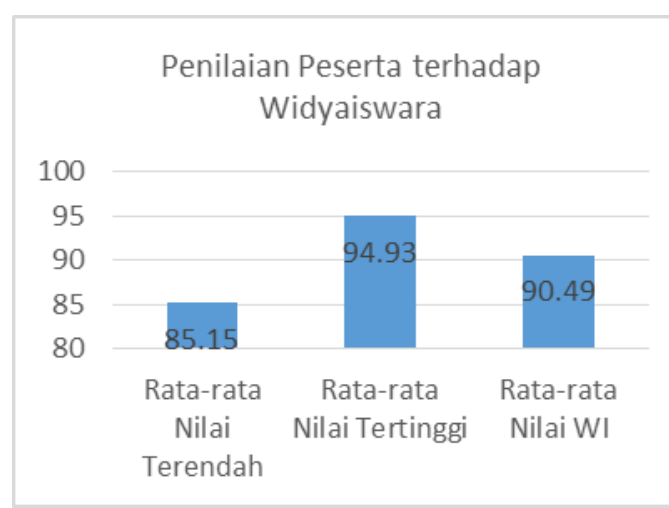

Grafik 1. Penilaian Peserta Terhadap Widyaiswara

Dalam evaluasi program Diklat diperlukan standar penilaian sesuai kategori seperti yang tecantum pada Surat Keputusan Kepala Badan Litbang dan Diklat Nomor 60 Tahun 2012 tentang Standar Kediklatan Teknis Kementerian Agama menyatakan bahwa hasil penilaian terhadap Widyaiswara secara kumulatif minimal 76. Sedangkan di Balai Diklat Keagamaan Bandung berdasarkan hasil rapat kerja BDK Bandung disepakati bahwa hasil penilaian terhadap widyaiswara secara kumulatif minimal 80. Dalam tabel terlihat bahwa rerata nilai 
terendah 85.15 , sedangkan rata-rata nilai tertinggi 94.93, dan nilai ratarata peserta terhadap widyaiswara adalah 90.49. Dengan hasil penilaian peserta terhadap widyaiswara 90.49 , maka terlihat bahwa nilai rata-rata widyaiswara sudah di atas standar minimal penilaian widyaiswara (80). Pelatihan Latsar ini, adalah salah satu pelatihan yang berorientasi pada tercapainya kebutuhan individu dalam upaya memenuhi komunitas tertentu, khususnya semua pegawai yang ada di bawah naungan Kementerian Agama. Kompetensi yang diperoleh peserta ketika mengikuti kegiatan Latsar, akan sangat dipengaruhi oleh tingkat kompetensi pengajar yang berinteraksi dengannya selama kurun waktu yang telah ditetapkan. Dari perolehan penilaian widyaiswara yang diatas rata-rata standar minimal, menunjukkan bahwa widyaiswara sudah kompeten.

Label kompeten yang diperoleh widyaiswara ini, tidak terlepas dari pembinaan yang selama ini dilakukan baik oleh Pusdiklat Tenaga Administrasi, Balai Diklat Keagamaan Bandung sebagai pelaksana, maupun LAN sebagai instansi Pembina. Pola Latsar yang baru ini menuntut widyaiswara menguasai seluruh substansi yang akan diberikan pada peserta, karena seorang fasilitator yang baik itu harus merencanakan kegiatan dengan baik, memberikan tugas yang jelas serta memeriksanya, membahas tugas-tugas mahasiswa, bersama peserta mempraktekkan penerapan konsep, melakukan komunikasi yang baik dengan sabar dan fleksibel, dan mengembangkan keterampilan dalam pengelolaan waktu dalam pembelajaran.
Dengan tuntutan kehidupan pada abad revolusi industri 4.0 serta menyongsong era Society 5.0, dimana tuntutan communicative skill, collaborative skill, critical thingking skill dan creative skill, menjadi tuntutan para pengajar termasuk widyaiswara, maka pengajar inipun dituntut untuk segera berpindah atau bermigrasi pada metode atau strategi pembelajaran yang lebih responsif terhadap perkembangan zaman (Wahyuni, 2020, 200)

Seorang widyaiswara profesional, sebagaimana dikemukakan oleh Sudjana, (2007) disyaratkan memiliki kemampuan dasar: a) akademik, yaitu kemampuan penguasaan materi pelatihan yang mencakup penguasaan wawasan dan pengembangan keilmuan yang sesuai dengan tanggung jawab mata diklat yang diembannya, sesuai latar belakang pendidikan dan TOT (Trainer of Traine)nya; b) kemampuan personal, yaitu integritas terhadap kematangan berfikir dan bertindak, pengelolaan emosi, serta memiliki motivasi internal yang kuat; c) kemampuan sosial yang berkaitan dengan kecakapannya dalam membina hubungan yang baik sesama widyaiswara, dengan panitia dan peserta, mewujudkan suasana saling asah, saling asih dan saling asuh.

3. Kepanitiaan

Untuk kelancaran pelaksanaan Latsar, dibentuk kepanitiaan dengan susunan sebagai berikut; Penanggung Jawab, Ketua, Sekretaris dan dua orang anggota. Berikut ini adalah grafik penilaian peserta Diklat terhadap kepanitiaan yang terdiri dari aspek yaitu kepesertaan, kepanitiaan, akomodasi, kurikulum, konsumsi dan 
sarana diklat.

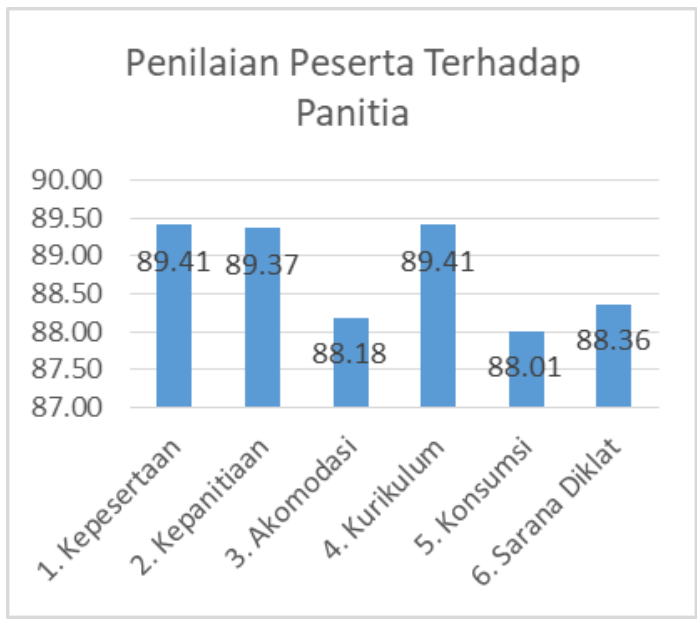

Grafik 2. Penilaian Peserta Terhadap Panitia

Dari grafik tersebut, terlihat bahwa nilai tertinggi diperoleh pada aspek kepesertaan dan kurikulum (89.41) sedangkan nilai terendah terdapat pada aspek konsumsi (88.01).

Aspek kepersertaan mendapat nilai tertinggi, karena peserta sudah dialokasikan dalam anggaran pada tahun berjalan dengan pendataan yang rapi, peserta dapat mempersiapkan segala sesuatu yang berkaitan dengan pelaksanaan kegiatan pada rentang waktu yang cukup lama. Jika peserta sudah bertugas di masing-masing tempat tugasnya, maka mereka bisa mempersiapkan penugasan yang akan diserahkan kepada rekan sejawatnya dengan baik. Seorang calon peserta yang bertugas sebagai guru, misalnya, maka jauh-jauh hari dia sudah mempersiapkan Rencana Pelaksanaan Pembelajaran (RPP), materi yang harus dibahas selama mengikuti Latsar, dan lain-lainnya pada guru rekan sejawatnya yang akan menggantikan posisinya di kelas.

Di aspek kurikulum, mendapat nilai tertinggi pula, karena Kurikulum Latsar dengan pola baru (Perkalan No. 12 Tahun 2018 tentang Pelatihan Dasar
(PNS), sudah dilakukan uji coba dan evaluasi dengan baik oleh Instansi Pembina, dalam hal ini Lembaga Administrasi Negara.

Penyusunan kurikulum yang dilaksanakan, sudah didasarkan pada lima prinsip, sebagaimana disyaratkan oleh Sudjana (2007), yaitu: a) kurikulum didasarkan pada upaya mewujudkan tatanan baru yang sesuai dengan budaya masyarakat, b) kurikulum yang didasarkan pada msyarakat baru yang lebih demokratis, c) kurikulum yang didasarkan pada misi perguruan tinggi yang dikondisikan pada kekuatan sosial, budaya dan ekonomi, d) peserta pelatihan sebagai sumber daya yang penting dalam rekonstruksi sosial melalui kegiatan akademik dan e) kurikulum harus mampu memecahkan krisi sosial, ekonomi dan budaya dalam kehidupan bermasyarakat.

Aspek konsumsi mendapat nilai terendah walaupun masih dalam kategori baik. Pertama, ini bukan diakibatkan oleh menu makanan atau penyajian yang kurang baik, tetapi lebih karena beberapa jenis menu tidak familiar atau belum cocok dengan lidah peserta Diklat yang berasal dari 26 kota dan kabupaten di Jawa Barat, yang sangat beragam menu lokalnya. Kedua, peserta bosan dengan rutinitas pola makan yang terjadwal ketat, seringkali ketika tiba waktu makan, mereka belum merasa lapar, sehingga mereka mengurangi porsi atau tidak makan.

\section{Peserta}

Kepersertaan terdiri dari 40 orang/angkatan, kecuali angkatan XXI hanya 20 orang, terdiri dari calon Dosen, calon Guru dan calon Pelaksana.

Tabel 1. Rata-rata Nilai Akhir Peserta 


\begin{tabular}{|l|r|l|r|}
\hline \multicolumn{1}{|c|}{ Angkatan } & \multicolumn{1}{c|}{ Nilai } & Angkatan & Nilai \\
\hline I & 86.31 & XI & 90.65 \\
\hline II & 84.61 & XII & 85.49 \\
\hline III & 85.59 & XIII & 85.83 \\
\hline IV & 85.66 & XIV & 85.83 \\
\hline V & 86.67 & XV & 86.37 \\
\hline VI & 86.93 & XVI & 88.52 \\
\hline VII & 87.33 & XVII & 87.38 \\
\hline VIII & 87.28 & XVIII & 87.98 \\
\hline IX & 87.68 & XIX & 86.39 \\
\hline X & 86.43 & XX & 86.63 \\
\hline \multicolumn{2}{|l|}{} & XXI & 85.83 \\
\hline Rata-rata & \multicolumn{2}{|c}{} \\
\hline
\end{tabular}

Berdasarkan Perkalan No. 12 Tahun 2018 tentang Pelatihan Dasar CPNS disebutkan bahawa kualifikasi penilaian evaluasi peserta Pelatihan Dasar CPNS ditetapkan: sangat memuaskan (skor 90,01 - 100); memuaskan (skor 80,01 - 90,0); cukup memuaskan (skor 70,01 - 80,0); kurang memuaskan (skor 60,01 - 70,0); dan tidak memuaskan (skor $\leq 60$ ). Dan peserta Pelatihan Dasar CPNS dinyatakan lulus apabila memperoleh kualifikasi paling rendah cukup memuaskan. Dari tabel terlihat bahwa nilai akhir peserta rata-rata 86.73 , ini berada pada rentang memuaskan, dan dinyatakan lulus.

Nilai rata-rata tertinggi terjadi pada Angkatan XI, sebesar 90,65. Hal ini dimungkinkan kemampuan pengetahuan peserta yang memang sudah bagus. Setelah dilakukan kroscek, ternyata hampir $40 \%$ peserta di Angkatan XI ini dari formasi Dosen. Wajar bila mereka memiliki kemampuan akademik yang bagus sebab berijazah S2 dari Institut Teknologi Bandung (ITB), Universitas Padjajaran (Unpad), dan Universitas Pendidikan Indonesia (UPI). Kemampuan mereka dalam menyerap materi yang diberikan Widyaiswara sangat cepat dan tepat, komunikasi dalam kegiatan berdiskusi terjadi dengan lancar. Hampir 95\% soal-soal ujian dikerjakan dengan waktu yang singkat.

\section{c. Proses}

1. Kegiatan Pembelajaran

Pembentukan Karakter

Kegiatan pembelajaran untuk pembentukan karakter ini terdiri dari tiga mata diklat, yaitu; Wawasan Kebangsaan dan Nilai-Nilai Bela Negara (6 jp), Analisis Isu Kontemporer (9 jp) dan Kesiapsiagaan Bela Negara (30 jp).

Tabel 2. Rata-rata Nilai Sikap dan Perilaku Peserta

\begin{tabular}{|l|r|l|r|}
\hline Angkatan & $\begin{array}{l}\text { Nilai Sikap } \\
\text { \& Perilaku }\end{array}$ & Angkatan & $\begin{array}{r}\text { Nilai Sikap } \\
\text { \& Perilaku }\end{array}$ \\
\hline I & 91.90 & XII & 93.00 \\
\hline II & 87.20 & XIII & 90.80 \\
\hline III & 43.60 & XIV & 95.30 \\
\hline IV & 88.60 & XV & 95.30 \\
\hline V & 100.00 & XVI & 48.10 \\
\hline VI & 48.00 & XVII & 44.80 \\
\hline VII & 88.50 & XVII & 91.50 \\
\hline VIII & 88.50 & XIX & 91.50 \\
\hline IX & 92.10 & XX & 94.00 \\
\hline X & 91.90 & XXI & 94.00 \\
\hline XI & 187.20 & & 87.90 \\
\hline \multicolumn{4}{|c|}{ Rata-rata } \\
\hline
\end{tabular}

Pada Pasal 18 dijelaskan bahwa penilaian sikap perilaku mendapat bobot $10 \%$, yang diuraikan sebagai berikut: a) dari Lembaga Terakreditasi (dalam hal ini Balai Diklat Keagamaan Bandung) sebesar 5\%, dan b) dari Instansi Pemerintah asal peserta (dalam hal ini UIN Bandung, IAIN Cirebon dan Kantor Kementerian Agama tiap kabupaten atau Kota di Jawa Barat) sebesar $5 \%$.

Pada tabel 2 di atas, Nilai sikap yang diperoleh peserta terdiri dari dua aspek, yaitu sikap yang diobservasi oleh BDK Bandung (5\%) dan nilai sikap yang diberikan oleh satkernya (5\%). Nilai Sikap yang diberikan kepada peserta, terdiri dari empat aspek, yaitu: a) Kedisiplinan (1\%); b) kepemimpinan (2\%); c) kerjasama (1\%); dan d) Prakarsa (1\%). Aspek sikap ini dilihat dari seluruh kegiatan peserta, baik di kelas, di lapangan ketika melaksanakan kegiatan 
Bela Negara, di asrama, ketika melaksanakan kegiatan di luar pembelajaran. Di Satker, ketika mereka melaksanakan kegiatan habituasi, yang langsung dibimbing oleh mentor masing-masing yang sekaligus pula atasannya langsung. Jadi komposisi total nilai sikap secara keseluruhan sebesar $10 \%$.

2. Kegiatan Pembelajaran Penguatan Kompetensi Teknis

Kegiatan pembelajaran untuk penguatan kompetensi teknis terdiri dari: (a) Nilai-nilai Dasar PNS: Akuntabilitas PNS, Nasionalisme, Etika Publik, Komitmen Mutu, Anti Korupsi, dengan masing-masing jumlah jp adalah 12 jp (9 jp teori dan 3 jp praktek); dan (b) Kedudukan dan Peran PNS dalam NKRI.

Tabel 3. Rata-rata Nilai Penguatan Kompetensi Bidang

\begin{tabular}{|l|l|l|l|}
\hline Angkatan & Nilai & Angkatan & Nilai \\
\hline I & 85.50 & XII & 87.55 \\
\hline II & 89.75 & XIII & 91.05 \\
\hline III & 100.00 & XIV & 93.35 \\
\hline IV & 91.95 & XV & 90.20 \\
\hline V & 86.95 & XVI & 100.00 \\
\hline VI & 94.05 & XVII & 99.50 \\
\hline VII & 93.35 & XVIII & 93.35 \\
\hline VIII & 89.90 & XIX & 91.30 \\
\hline IX & 94.40 & XX & 93.35 \\
\hline X & 91.20 & XXI & 93.35 \\
\hline XI & 72.75 & & \\
\hline Rata-rata & & 91.56 \\
\hline
\end{tabular}

d. Produk

1. Rancangan Aktualisasi

Tabel 4. Rata-rata Nilai Rancangan Aktualisasi

\begin{tabular}{|c|c|c|c|}
\hline Angkatan & Nilai & Angkatan & Nilai \\
\hline I & 85.45 & XII & 84.7 \\
\hline II & 84.45 & XIII & 85.45 \\
\hline III & 88.1 & XIV & 87.9 \\
\hline IV & 86.35 & $\mathrm{XV}$ & 86.95 \\
\hline $\mathrm{V}$ & 85.45 & XVI & 87.6 \\
\hline VI & 90.1 & XVII & 88.1 \\
\hline VII & 87.9 & XVIII & 87.9 \\
\hline VIII & 87.1 & XIX & 85.75 \\
\hline IX & 87.9 & $\mathrm{XX}$ & 85.5 \\
\hline $\mathrm{X}$ & 85.25 & $\mathrm{XXI}$ & 87.9 \\
\hline $\mathrm{XI}$ & 86.9 & & \\
\hline \multicolumn{3}{|c|}{ Rata-rata } & 86.80 \\
\hline
\end{tabular}

Rancangan aktualisasi ini dinilai berdasarkan beberapa aspek, 1) kualitas penerapan isu, dengan poin tertinggi pada isu yang diangkat aktual dan berdampak pada unit kerja atau cakupan yang lebih luas. Misalnya bila peserta sebagai seorang guru, maka isu yang paling hangat dalam proses pembelajaran adalah bagaimana dia dapat memformulasikan kegiatan pembelajaran yang menyenangkan, tidak membuat peserta didik merasa bosan dan hal terpentingnya, bagaimana mengoptimalkan pembelajaran di kelas dengan sarana dan prasarana pembelajaran yang terbatas, agar suasana kelas tidak menjadi hal yang membuat peserta didik untuk mengikuti kegiatan pembelajaran tidak surut (Nurjanah dan Aryani, 2020, 220); 2) jumlah kegiatan yang dilaksanakan pada saat aktualisasi; 3) kualitas kegiatan dengan poin tertinggi pada Kegiatan yang dipilih relevan dengan penyelesaian isu, penyusunan tahapan tergambar jelas; 4) relevansi kegiatan dengan aktualisasi; dan 5) teknik komunikasi 
2. Kegiatan Habituasi

Tabel 5. Rata-rata Nilai Penguatan Kompetensi Bidang

\begin{tabular}{|c|c|}
\hline Angkatan & Nilai Habituasi \\
\hline I & 88.7 \\
\hline II & 88.475 \\
\hline III & 71.8 \\
\hline IV & 90.275 \\
\hline VI & 93.475 \\
\hline VII & 71.025 \\
\hline VIII & 90.925 \\
\hline IX & 89.2 \\
\hline X & 93.25 \\
\hline XI & 91.55 \\
\hline XII & 86.375 \\
\hline XIII & 90.275 \\
\hline XIV & 90.925 \\
\hline XV & 94.325 \\
\hline XVI & 92.75 \\
\hline XVII & 74.05 \\
\hline XVIII & 72.15 \\
\hline XIX & 92.425 \\
\hline XX & 91.4 \\
\hline XXI & 93.675 \\
\hline Rata-rata & 93.675 \\
\hline \multicolumn{2}{|c|}{} \\
\hline
\end{tabular}

Kegiatan habituasi ini adalah kegiatan yang dilaksanakan peserta di tempat tugasnya masing-masing, dengan pengawasan mentor yang sekaligus atasannya langsung di tempat tugasnya. Pada kegiatan habituasi ini, dilakukan pula penilaian sikap dan penilaian kompetensi bidang oleh satkernya. Nilai Habituasi yang diberikan oleh satkernya dikirimkan secara tertutup kepada panitia di BDK Bandung, bisa melalui email ataupun alat komunikasi lainnya. Sehingga penilaian semacam ini akan menjaga marwah peserta, baik sesama teman sejawatnya maupun pihak-pihak lain yang tidak berkepentingan. Nilai Habituasi yang diberikan oleh satkernya masing-masing akan diolah sekaligus dengan nilai-nilai pada berbagai aspek yang diberikan oleh BDK, pada pembahasan sebelumnya pada Tabel Rata-rata Nilai Sikap dan Perilaku Peserta (setelah digabung menjadi sebesar $10 \%$ dari porsi keseluruhan).

Dari Tabel 5 diatas, nilai tertinggi $(94,325)$ diperoleh angkatan XIV dan nilai terendah $(71,7)$ diperoleh angkatan
III. Sedangkan nilai rata-rata keseluruhan kegiatan habituasi ini sebesar 87,65 . Hal ini menunjukkan bahwa kegiatan habituasi ini mendapat respon yang positif dari lingkungan kerja masingmasing peserta. Ini sejalan dengan pendapat Samani dan Haryanto dalam Modul Latsar CPNS Habituasi (Utomo W. dkk., 2017) tentang habituasi, agenda habituasi digunakan untuk menghasilkan suatu penciptaan situasi dan kondisi tertentu yang memungkinkan peserta melakukan proses pembiasaan untuk berperilaku sesuai kriteria tertentu. Penciptaan situasi ini dimaksudkan untuk pembentukan karakter baik karakter diri yang ideal melalui proses internalisasi maupun pembiasaan diri melalui intervensi tertentu yang akan dilakukan pada pelaksanaan tugas jabatan di tempat kerjanya. Intervensi ini diciptakan untuk memicu timbulnya suatu respon yang diawali dari hal-hal kecil atau yang paling mendasar dibutuhkan di tempat kerjanya, diantaranya aktivitas rutin dalam menyelesaikan pekerjaan, kualitas kerja, jam kerja, kedisiplinan, cara dan etika memberikan pelayanan kepada konsumen, komunikasi dengan sesama pegawai atau dengan pimpinan, dll.

\section{Laporan Pelaksanaan Aktualisasi}

Laporan Pelaksanaan aktualisasi dikerjakan oleh peserta diklatdi tempat kerjanya selama masa off campus, baik harian, mingguan atau periode tertentu sesuai kesepakatan bimbingan dengan Coach dan mentor dengan memanfaatkan berbagai macam media komunikasi untuk mempermudah komunikasi dalam proses pembimbingan. Pelaksanaan pembimbingannya dimulai dari hari pertama peserta pelatihan kembali ke tempat kerja hingga peserta kembali ke 
tempat pelatihan. Setelah menyelesaikan laporan aktualisasi, kemudian peserta Pelatihan Dasar CPNS dituntut untuk mempresentasikan hasil aktualisasi. Berikut ini adalah rata-rata nilai pelaksanaan aktualisasi untuk masingmasing angkatan.

Tabel 6. Rata-rata Penilaian Pelaksanaan Aktualisasi

\begin{tabular}{|l|l|l|l|}
\hline Angkatan & Nilai & Angkatan & Nilai \\
\hline I & 87.53 & XII & 86.87 \\
\hline II & 86.97 & XIII & 87.70 \\
\hline III & 90.03 & XIV & 89.57 \\
\hline IV & 88.27 & XV & 88.23 \\
\hline V & 86.33 & XVI & 83.33 \\
\hline VI & 89.57 & XVII & 90.03 \\
\hline VII & 89.57 & XVIII & 89.57 \\
\hline VIII & 89.10 & XIX & 88.80 \\
\hline IX & 88.13 & XX & 87.43 \\
\hline X & 89.37 & XXI & 89.57 \\
\hline XI & 78.00 & & 87.81 \\
\hline \multicolumn{5}{|c}{} \\
\hline
\end{tabular}

Nilai pelaksanaan aktualisasi didasarkan pada beberapa komponen, yaitu: 1) kualitas pelaksanaan kegiatan dengan poin tertinggi bila peserta mampu melaksanakan seluruh kegiatan yang sudah direncanakan dan melahirkan gagasan kreatif dengan persetujuan pembimbing; 2) kualitas aktualisasi, dengan aspek tertinggi pada aktualisasi nilai-nilai dasar PNS dan kedudukan dan peran PNS dalam NKRI yang mendasari kegiatan bermanfaat bagi stakeholder dan/atau pimpinan, berkontribusi terhadap pencapaian visi, misi dan tujuan organisasi, serta memperkuat nilai organisasi; dan 3)

\section{PENUTUP}

\section{Simpulan}

Berdasarkan pembahasan di atas, maka disimpulkan:

a) Conteks Pelatihan Dasar CPNS Tahun 2019 di Balai Diklat Keagamaan teknik komunikasi dengan nilai terbesar pada aspek kemampuan menjelaskan hasil aktualisasi dengan baik dan mampu merespon pertanyaan dari para penguji.

Ketiga poin di atas, diwujudkan peserta dalam bentuk laporan aktualisasi dengan format yang sudah ditentukan. Terdiri dari lima bab (Pendahuluan, Analisis Isu dan Gagasan Solusi, Rancangan Aktualisasi, Pelaksanaan Aktualisasi dan Penutup). Laporan ini mereka susun setelah melaksanakan kegiatan habituasi dengan waktu yang telah ditentukan. Kegiatan mulai dari rancangan aktualisasi sampai menjadi laporan aktualisasi, dibimbing oleh seorang coach, yang sudah ditunjuk sesuai bidang garapannya. Coach ini bisa widyaiswara, atau pejabat struktural BDK. Seorang coach mendampingi 5 10 peserta.

Contoh-contoh Laporan Aktualisasi yang sudah dilaksanakan oleh peserta adalah:

Tabel 7. Contoh Laporan Aktualisasi

\begin{tabular}{|l|l|l|}
\hline No & Jabatan Peserta & Judul Laporan Aktualisasi \\
\hline 1 & Pustakawan & $\begin{array}{l}\text { Optimalisasi Media Sosial Perpustakaan sebagai Sarana } \\
\text { Komunikasi antara Perpustakaan dengan Pemustaka }\end{array}$ \\
\hline 2 & Dosen & $\begin{array}{l}\text { Optimalisasi Pelayanan Rekomendasi melalui Aplikasi } \\
\text { SIMAKSPI pada Fakultas Psikologi UIN SGD Bandung }\end{array}$ \\
\hline 3 & Dosen & $\begin{array}{l}\text { Optimalisasi Penyimpanan File Data Kepegawaian Berbasis } \\
\text { WEB Fakultas Dakwah dan Komunikasi UIN SGD Bandung }\end{array}$ \\
\hline 4 & Guru & $\begin{array}{l}\text { Penerapan Model Pembelajaran Problem Based Learning } \\
\text { (PBL) pada Pelajaran Matematika Kelas XII IPS di MAN 3 } \\
\text { Sukabumi }\end{array}$ \\
\hline 5 & Guru & $\begin{array}{l}\text { Menumbuhkan Kebiasaan Belajar Mandiri dengan penerapan } \\
\text { One Day One Questions (ODOQ) di MIN I Ciamis }\end{array}$ \\
\hline 7 & $\begin{array}{l}\text { Komanata } \\
\text { Widyaiswara }\end{array}$ & $\begin{array}{l}\text { Pelayanan Cuti Pegawai melalui Optimalisasi E-Office di BDK } \\
\text { Bandung }\end{array}$ \\
\hline 8 & $\begin{array}{l}\text { Pembuatan SOP dan Panduan Penggunaan Penggunaan } \\
\text { Paboratorium Bahasa di BDK Bandung }\end{array}$ \\
\hline
\end{tabular}

Bandung tidak terlepas dari panduan sumber hukum yang menjadi pijakan seluruh pelaksanaan kegiatannya, yaitu: sumber hukum yang diterbitkan LAN maupun Pusdiklat.

b) Input Pelatihan Dasar CPNS Tahun 2019 di Balai Diklat Keagamaan 
Bandung terdiri dari empat komponen, yaitu; 1) kurikulum yang sudah ditetapkan oleh LAN, sebanyak 511 jp; 2) widyaiswara sebanyak 8 orang berasal

dari BDK Bandung, Pusdiklat Administrasi, Lembaga Administrasi Negara, Pejabat Struktural, TNI dan beberapa Widyaiswara yang sudah purna tugas; 3) kepanitiaan, terdiri dari Penanggung Jawab, Ketua, Sekretaris dan dua orang anggota; dan 4) peserta, terdiri dari 40 orang/angkatan, kecuali angkatan XXI hanya 20 orang, terdiri dari calon Dosen, calon Guru dan calon Pelaksana

c) Proses Pelatihan Dasar CPNS Tahun 2019 di Balai Diklat Keagamaan Bandung terbagi menjadi: 1) Kegiatan Pembelajaran Pembentukan Karakter, diperoleh nilai rata-rata 83,74; dan 2) Kegiatan Pembelajaran Penguatan Kompetensi Teknis, diperoleh nilai rata-rata 91,56 . d) Produk Pelatihan Dasar CPNS Tahun 2019 di Balai Diklat Keagamaan Bandung, terdiri dari: 1) Rancangan Aktualisasi, diperoleh nilai rata-rata 86,80 ; 2) Kegiatan Habituasi, diperoleh nilai rata-rata 87,65; dan 3) Laporan Pelaksanaan Aktualisasi, diperoleh nilai rata-rata 87,81 .

\section{Rekomendasi}

Dari simpulan di atas tergambar bahwa kegiatan Pelatihan Dasar CPNS 2019 di Balai Diklat Keagamaan Bandung sudah berjalan dengan baik, tinggal mempertahankan dan meningkatkan kegiatan yang sudah berjalan. Perlu ada penelitian lebih lanjut untuk menambah kedalaman penelitian ini. 


\section{DAFTAR PUSTAKA}

Anggraini, D. (2013). Pengembangan Kompetensi Aparatur Di Badan Perencanaan Dan Pembangunan Daerah Kota Samarinda (Studi Evaluasi Keputusan Kepala BAdan Kepegawaian Negara No 43 Tahun 2001 Tentang Standar Kompetensi Jabatan Struktural). EJournal Ilmu Pemerintahan.

Aryani, Asih. 2019. Supervisi Kepala Madrasah untuk Meningkatkan Kompetensi Paedagogik Guru. Sekolah Pasca Sarjana Uninus. Bandung. Tidak Diterbitkan

Basuki, A. (2017). Efektivitas Implementasi Diklat Prajabatan Kategori I dan II (Sesuai Peraturan Kepala LAN RI Nomor 18 Tahun 2014). Jurnal Lingkar Widyaiswara, Edisi 4(4), 29-40.

Berliana, Anne. (2014). Factor Motivasi untuk Menumbuhkan Belajar Peserta Diklat. Jurnal Inspirasi Volume 5 No 2, September 2014: 23-28

Handayani, W. T., Suryono, A., Said, A., Publik, J. A., Administrasi, F. I., \& Brawijaya, U. (2014). Efektivitas Pelaksanaan Pendidikan dan Pelatihan Kepemimpinan Pegawai Negeri Sipil. ( Studi di Badan Kepegawaian Daerah Kabupaten Probolinggo ). Jurnal Administrasi Publik (JAP).

Hanun, M.Pd, F. (2018). Evaluasi Penyelenggaraan Diklat Di Kementerian Agama. EDUKASI: Jurnal Penelitian Pendidikan Agama Dan Keagamaan, 16(2), 191-203.

Diambil kembali dari, https://doi.org/10.32729/edukasi.v16i2.477

Ismail, Fajri. 2014. Evaluasi Pendidikan. Tunas Gemilang. Palembang

Israwati. (2019). Efektivitas Pelaksanaan Diklat Prajabatan pada Badan Kepegawaian Pendidikan dan Pelatihan Kabupaten Mamasa. Jurnal Ilmu Pemerintahan \& Ilmu Komunikasi, 4(2).

Juanda. (2011). Program Evaluation on Job Training for Pre Position Level III. Jurnal Evaluasi Pendidikan,2(1).

Kadarisman, M. (2015). Analisis Pendidikan dan Pelatihan Dasar Keinstrukturan dalam Meningkatkan Kualitas Instruktur. Program Studi Magister Manajemen Pendidikan Pascasarjana Universitas Kristen Indonesia, 4(1), 45.

Moleong, Lexy. 2006. Metodologi Penelitian Kualitatif. Bandung: Rosdakarya

Mulyaningsih. (2016). Evaluasi Pelaksanaan Pendidikan dan Pelatihan Kompetensi Sumber Daya Aparatur (Studi di Badan Kepegawaian Daerah Kota Magelang). Jurnal Administrative Reform, 4(4).

Nata, Abuddin. 2009. IImu Pendidikan Islam, Jakarta: Rajawali Pers.

Nawawi, Hadari. 2007. Administrasi Pendidikan. Jakarta: Gunung Agung. 
Nuraini, N. (2019). Evaluasi Reaksi Peserta pada Penyelenggaraan Diklat di Pusdiklat Tenaga Teknis Pendidikan dan Keagamaan Tahun 2018. Andragogi: Jurnal Diklat Teknis Pendidikan Dan Keagamaan, 7(1), 1-17.

Diambil kembali dari, https://doi.org/10.36052/andragogi.v7i1.66

Nurjanah dan Aryani. (2020). Meningkatkan Hasil dan Motivasi Belajar Peserta Didik melalui Model Problem Based Learning. Tatar Pasundan Jurnal Diklat Keagamaan Volume 14 Nomor 2 Tahun 2020. pISSN 2085 - 4005, eISSN 2721 - 2866

Pardede, A. C., \& Mustam, M. (2017). Manajemen Sumber Daya Manusia Pegawai Negeri Sipil Dalam Rangka Reformasi Birokrasi Di Kabupaten Semarang. Journal of Public Policy and Management Review.

Peraturan Lembaga Administrasi Negara Nomor 12 tahun 2018

Raharjo, T. (n.d.). Efektivitas Diklat Prajabatan Pola Baru bagi Calon Pegawai Negeri Sipil Kementerian Keuangan. Politeknik Keuangan Negara STAN.

Rohaini, R. A., Hidayat, N., \& Sutisna, E. (2019). Evaluasi Pelatihan Dasar Calon Pegawai Negeri Sipil dalam Mendukung Terwujudnya Sumberdaya Manusia Profesional Berkarakter. JURNAL MANAJEMEN PENDIDIKAN.

Diambil kembali dari, https://doi.org/10.33751/jmp.v7i1.953

Sdm, D., \& Rahmawati, A. (2017). Efektivitas program penyelenggaraan Diklat SDM. Jurnal Ilmiah Manajemen Publik Dan Kebijakan Sosial.

Silvia, Mareta Mega. 2015. Evaluasi Program Pendidikan dan Pelatihan (Diklat) Pendamping Program Keluarga Harapan (PKH) Angkatan VIII di Balai Besar Pendidikan dan Pelatihan Kesejahteraan Sosial (BBPPKS) Yogyakarta. Jurnal Pendidikan Luar Sekolah. Universitas Negeri Yogyakarta

Sudjana. 2007. Sistem \& Manajemen Pelatihan, Teori dan Aplikasi. Bandung. Falah Production

Sukardi, 2014. Evaluasi Program Kependidikan dan Kepelatihan. Jakarta: Bumi Aksara.

Tulung, J. M. (2014). Evaluasi Program Pendidikan Dan Pelatihan Kepimpinan Tingkat IV Di Balai Diklat Keagamaam Manado. Journal “Acta Diurna."

Utomo, W. dkk. 2017. Modul Pelatihan Dasar Calon PNS Habituasi. Jakarta. LAN

Wahyuni, Leni Sri. (2020). Membangun Kompetensi Abad 21 melalui Metode Constructive Controversy pada Pembelajaran Bahasa Inggris. Tatar Pasundan Jurnal Diklat Keagamaan PISSN 2085-4005; EISSN 2721-2866 Volume XIV Nomor 2 Tahun 2020: 199-208.

Zakiyuddin, F. (2016). Evaluasi Program Diklat Administrasi Kepegawaian Pada Balai Diklat Keagamaan Kementerian Agama Jakarta (Implementasi Model Evaluasi Kirkpatrick). Jurnal Evaluasi Pendidikan, 7 (1), 33-42.

Diambil kembali dari, https://doi.org/10.21009/jep.071.04 